\title{
Preparation and Characterization of Environmental Functional Poly(Styrene-Co-2-[(Diethylamino)Methyl]- 4-Formyl-6-Methoxy-Phenyl Acrylate) Copolymers for Amino Acid Post Polymerization
}

\author{
Momen S. A. Abdelaty* \\ Polymer Lap, Chemistry Department, Faculty of Science (Assiut), Al-Azhar University, Cairo, Egypt \\ Email: *abdelatymomen@yahoo.com
}

How to cite this paper: Abdelaty, M.S.A. (2018) Preparation and Characterization of Environmental Functional Poly(Styrene-Co-2-[(Diethylamino)Methy ]-4-Formyl-6-Methoxy-Phenyl Acrylate) Copolymers for Amino Acid Post Polymerization. Open Journal of Polymer Chemistry, 8, 41-55.

https://doi.org/10.4236/ojpchem.2018.8300 $\underline{5}$

Received: April 30, 2018

Accepted: June 29, 2018

Published: July 2, 2018

Copyright $\odot 2018$ by author and Scientific Research Publishing Inc. This work is licensed under the Creative Commons Attribution International License (CC BY 4.0).

http://creativecommons.org/licenses/by/4.0/

\begin{abstract}
Vanillin was used as renewable resource for preparing new monomer in two stops. The monomer has tertiary amine group which facilitates the $\mathrm{pH}$ change and functional aldehyde group that encourages the formation of Schiff base. It was abbreviated by DEAMVA and evaluated using chemical analysis e.g. ${ }^{1} \mathrm{H}$ NMR, ${ }^{13} \mathrm{C}$ NMR and FT IR all data were in logic case. Copolymerization of Styrene with 5 and 15 mol\% of DEAMVA has been done by free radical polymerization and AIBN as initiator. The copolymers have been chemically and physically characterized e.g. ${ }^{1} \mathrm{H}$ NMR, FT IR, GPC, and DSC. Post polymerization of poly (styrene-Co-DEAMVA) with $15 \mathrm{~mol} \%$ (III b) was prepared for immobilization of tryptophan and investigated by the same methods used lately. Moreover, the sensitivity of the posted copolymer to $\mathrm{pH}$ has also studied by UV-vis. Spectroscopy. Scanning electron microscopy (SEM) was used to study the morphological feature of polymer surface after immobilization of tryptophan.
\end{abstract}

\section{Keywords}

Environmental, Functional, Styrene, Vanillin, Amino Acid, Post Polymerization

\section{Introduction}

Environmental $\mathrm{pH}$-responsive polymers are polyelectrolytes that have weak 
acidic or basic groups in their structure and either accept or release protons in response to changes in environmental $\mathrm{pH}$. The acidic or basic groups on polyelectrolytes undergo ionization just like acidic or basic groups of mono-acids or mono-basic [1] [2]. By generating the charge along the polymer backbone, the electrostatic repulsion results in an increase in the hydrodynamic volume of the polymer [3] [4]. This transition between tightly coiled and swollen state is influenced by any condition that modify electrostatic repulsion, such as $\mathrm{pH}$, ionic strength, and type of counter ions. The transition from collapsed state to expanded state has been explained by changes in the osmotic pressure exerted by mobile counter ions neutralizing the network charges [2]. Several applications for $\mathrm{pH}$-responsive polymers and hydrogel are especially in the field of biomedicine e.g. Drug delivery systems and Gene carriers [5]-[11].

Several scientists were looking for new alternatives of styrene monomer due to its disadvantages such as, hazardous air pollutants and emitting during metering mixing process and curing; additionally the unreacted styrene continues to be released from composites during life cycle [12]. Renewable resources like (cellulose, starch, natural oil... etc.) have been used as alternative to produce bio-based monomers [13]. The lignin produced from Vanillin becoming relatively easily accessible; still there are only a handful of reports on attempts to utilize vanillin as monomers for bio-based polymer synthesis [14] [15]. Several chemical modifications on vanillin have occurred due to the presence of both aldehyde and hydroxyl active groups [2] [16]. The dimerization and the Polymerization of vanillin through electrochemical reductive with horseradish peroxidase have recently been discussed [17].

Schiff's base has also been played a vital role in the coordination chemistry and was found to be stable under oxidative and reductive conditions [18]. Vanillin was used to prepare Schiff bases [19]. The biological activity of Schiff s base polymers have been widely reported by several authors [20] [21] [22] [23] [24]. The most interested articles used Schiff base as a stimuli-responsive linker in the polymer chain which has been published by Yuan et al. [25]. The imine linkage is very sensitive to $\mathrm{pH}$ value which is responsible on the responsive feature of the polymer molecule [26] [27]. The formation of complexes with the imine can also be used to demonstrate the $\mathrm{pH}$ responsiveness of the linker [28]-[33]. Several publications have reported "click chemistry" as linkers for many bio-based molecules [34] [35] [36]. Here, we synthetized new functional polystyrene polymers by copolymerization with $\mathrm{pH}$-responsive monomer from vanillin as renewable resource. The aldehyde group in the copolymer chain was used for grafting biomolecule by Schiff base click reaction. In future our work will focus on the applications of these kinds of polymers and their gel in the bio-separation for many kinds of biological macromolecule.

\section{Experimental}

\subsection{Material}

Acryloyl chloride (98\% Merck), (AIBN Acrōs) 2,2'-azobis (isobutyronitrile) was 
recrystallized from methanol, styrene (99\% Acrōs), vanillin (99\% Acrōs), triethylamine (Merck), tryptophan (97\% Acrōs). Dichloromethane, toluene, tetrahydrofuran (THF), and diethylether were distilled over potassium hydroxide. Other chemicals were used as received.

\subsection{Instruments}

Bruker AV 500 spectrometer was used to record ${ }^{1} \mathrm{H}$ and ${ }^{13} \mathrm{C}$ NMR spectra in DMSO d $\mathrm{d}^{6}$ or $\mathrm{CDCl}_{3}$ at $500 \mathrm{MHz}$ and $125 \mathrm{MHz}$, respectively. Vertex 70 Fourier transform infrared instrument for recording IR spectra. The samples were milled with dry potassium bromide $\mathrm{KBr}$ (Merck 99\%) and pressed to pellets. The Molecular weights $(\mathrm{M})$ and polydispersity $(\mathrm{D})$ were analysed by size exclusion chromatography (SEC). Chloroform was used as eluent (containing of $0.1 \mathrm{vol} \%$ triethylamine) with a flow rate of $0.75 \mathrm{~mL} / \mathrm{min}$ (Jasco $880-\mathrm{PU}$ pump) with a Waters RI-Detector and toluene as internal standard at $30^{\circ} \mathrm{C}$. The samples $(15$ $\mathrm{mg} / \mathrm{mL}$ ) were injected by hand via a $20 \mu \mathrm{L}$ loop. PSS-SDV columns filled with 5 $\mu \mathrm{m}$ gel particles with a defined porosity of $10^{6} \AA$ (guard), $10^{5} \AA, 10^{3} \AA$ and $10^{2} \AA$ respectively were used. Molecular weight determination was based on narrow polystyrene standards. UV/vis spectrometer (Perkin Elmer Lambda 45) was used to determine the concentration of amino acid in grafted polymer. The $\mathrm{pH}$ of polymer solution was in THF and measured by pH-meter model VWR pH 100. Perkin Elmer Differential Scanning Calorimeter (DSC) Pyris 1 was used for the determination of $T_{g}$ of solid polymers. The thermogram was recorded at heating and cooling rate of $5^{\circ} \mathrm{C} / \mathrm{min}$. The morphology of the polymer were examined by Scanning Electron Microscopy (SEM) using a Zeiss NEON 40 instrument (USA); $2 \mathrm{kV}(30 \mu \mathrm{m}$ aperture). Sputter coater is a Bal-Tec SCD 500 with a film thickness monitor QSG 100. We applied approx. $4 \mathrm{~nm}$ of gold-palladium ( $\mathrm{Au}: \mathrm{Pd}=80: 20)$.

\subsection{Synthesis of Monomer}

Synthesis of

2-[(Diethylamino)Methyl]-4-Formyl-6-Methoxy-Phenyl Acrylate (DEMAVA)

\section{Step 1: Synthesis of}

\section{3-[(Diethylamino)Methyl)-4-Hydroxy-5-Methoxybenzaldhyde}

A mixture of $10 \mathrm{~g}$ ( $0.065 \mathrm{~mol})$ of vanillin, (4-hydroxy-3-methoxybenzaldehyde), $10 \mathrm{~g}(0.33 \mathrm{~mol})$ of formaldehyde and $10 \mathrm{~g}$ of diethylamine $(0.136 \mathrm{~mol})$ was dissolved in $150 \mathrm{~mL}$ ethanol in $250 \mathrm{~mL}$ round bottomed flask fitted with reflux condenser. The mixture was refluxed in oil bath at $90^{\circ} \mathrm{C}-100^{\circ} \mathrm{C}$ for $3 \mathrm{~h}$. The mixture allowed cooling to room temperature. The solvent was removed under reduced pressure to collect the product. Yield\%: 97\%, Physical state: Yellowish white solid.

${ }^{1} \mathrm{H}$ NMR $\left(500 \mathrm{MHz}, \mathrm{CDCl}_{3}\right): \delta(\mathrm{ppm})=1.18\left(\mathrm{t}, 6 \mathrm{H}, 12-\mathrm{CH}_{3}\right), 1.26($ br., s, $1 \mathrm{H}$, 8-OH), $2.73\left(\mathrm{q}, 4 \mathrm{H}, 11-\mathrm{CH}_{2}\right), 3.92\left(\mathrm{~s}, 2 \mathrm{H}, 9-\mathrm{CH}_{2}\right), 3.94\left(\mathrm{~s}, 3 \mathrm{H}, 7-\mathrm{CH}_{3}\right), 7.25,7,34$ (dd, $2 \mathrm{H},{ }^{4} \mathrm{~J}=1.6,3.3^{-}-\mathrm{Ar}-\mathrm{CH}, 10-\mathrm{NH}^{+}$), 9.77 (s, 1H, 1-CHO).

${ }^{13} \mathrm{C}-\mathrm{NMR}\left(125 \mathrm{MHz}, \mathrm{CDCl}_{3}\right): \delta(\mathrm{ppm})=10.82\left(2 \mathrm{C}, 12-\mathrm{CH}_{3}\right), 46.35(2 \mathrm{C}$, 
11- $\mathrm{CH}_{2}$ ), 55.85 (1C, 10- $\mathrm{CH}_{2}$ ), 56.01 (1C, 8-CH3), 109.68 (1C, 4- $\left.\mathrm{Ar}-\mathrm{CH}\right), 120.84$ (1C, 4-Ar-CH), 125.75 (1C, 5-Ar-C), 127.99 (1C, 3-Ar-CH), 148.65 (1C, 6-Ar-CH), 154.87 (1C,7-Ar-C), 191.65 (1C, 2-C=O).

IR (KBr): v ( $\left.\mathrm{cm}^{-1}\right): 2987$ (s) $\left(\mathrm{CH}_{2}, \mathrm{CH}_{3}\right), 1650$ (s) (2-C=O,), 1706 (s) (7-C=O), 820 - $868(\mathrm{~m})(\mathrm{Ar}-\mathrm{CH})$.

\section{Step 2: Synthesis of 2-[(Diethylamino) \\ Methyl]-4-Formyl-6-Methoxyphenyl Acrylate}

$13.9 \mathrm{~g}(0.058 \mathrm{~mol})$ of

3-[(diethylamino) methyl)-4-hydroxy-5-methoxybenzaldhyde (I) was dissolved in $200 \mathrm{~mL}$ dry $\mathrm{CH}_{2} \mathrm{Cl}_{2}$ in two neck flask fitted with argon balloon. During stirring $12.3 \mathrm{~g}(0.12 \mathrm{~mol})$ of TEA was added. The reaction mixture allowed cooling in ice bath to $0^{\circ} \mathrm{C}-5^{\circ} \mathrm{C}$. After cooling, $5.4 \mathrm{~g}(0.059 \mathrm{~mol})$ acryloyl chloride was added drop wise. The yellowish suspension was stirred at $5^{\circ} \mathrm{C}$ for $1 \mathrm{~h}$, and then allowed to stir at RT for $6 \mathrm{~h}$. The precipitate was filtered and solvent was evaporated under reduced pressure. The product was extracted by $\mathrm{CH}_{2} \mathrm{Cl}_{2}$ and wash three times with $100 \mathrm{ml}$ dest. water then one time with $0.1 \mathrm{M} \mathrm{Na}_{2} \mathrm{CO}_{3}$, and again with $100 \mathrm{~mL}$ dest. Water, then product dried with $\mathrm{MgSO}_{4}$ overnight. Yield\%: 80\%, Physical state: Orange solid.

${ }^{1} \mathrm{H}$ NMR $\left(500 \mathrm{MHz}, \mathrm{CDCl}_{3}\right): \delta(\mathrm{ppm})=1.10\left(\mathrm{t}, 6 \mathrm{H}, 14-\mathrm{CH}_{3}\right), 2.48(\mathrm{q}, 4 \mathrm{H}$, $\left.13-\mathrm{CH}_{2}\right), 3.51\left(\mathrm{~s}, 2 \mathrm{H}, 11-\mathrm{CH}_{2}\right), 3.88\left(\mathrm{~s}, 3 \mathrm{H}, 7-\mathrm{CH}_{3}\right), 6.06\left(\mathrm{dd},{ }^{2} \mathrm{~J}=1.3 \mathrm{~Hz},{ }^{3} \mathrm{~J}=\right.$ $10.40 \mathrm{~Hz}, 1 \mathrm{H}, 10 \mathrm{a}-\mathrm{CH}), 6.37\left(\mathrm{dd},{ }^{3} \mathrm{~J}=10.40 \mathrm{~Hz},{ }^{3} \mathrm{~J}=17.30 \mathrm{~Hz}, 1 \mathrm{H}, 9-\mathrm{CH}\right), 6.63$ $\left(\mathrm{dd},{ }^{2} \mathrm{~J}=1.3 \mathrm{~Hz},{ }^{3} \mathrm{~J}=17.30 \mathrm{~Hz}, 10 \mathrm{~b}-\mathrm{CH}\right), 7.25,7.34\left(\mathrm{dd}, 3 \mathrm{H},{ }^{4} \mathrm{~J}=1.6,{ }^{4} \mathrm{~J}=1.9\right.$, 3.3--Ar-CH), 9.77 (s, 1H, 1-CHO).

${ }^{13} \mathrm{C}-\mathrm{NMR}\left(125 \mathrm{MHz}, \mathrm{CDCl}_{3}\right): \delta(\mathrm{ppm})=10.82\left(2 \mathrm{C}, 12-\mathrm{CH}_{3}\right), 46.35(2 \mathrm{C}$, $11-\mathrm{CH}_{2}$ ), 55.85 (1C, 10- $\mathrm{CH}_{2}$ ), 56.01 (1C, 8-CH3), 109.68 (1C, $\left.4^{-}-\mathrm{Ar}-\mathrm{CH}\right), 120.84$ (1C, 4-Ar-CH), 125.75 (1C, 5-Ar-C), 127.99 (1C, 3-Ar-CH), 148.65 (1C, 6-Ar-CH), 154.87 (1C, 7-Ar-C), 191.65 (1C, 2-C=O).

IR (KBr): v ( $\left.\mathrm{cm}^{-1}\right): 2987$ (s) $\left(\mathrm{CH}_{2}, \mathrm{CH}_{3}\right), 1650$ (s) (2-C=O,), 1706 (s) $(8-\mathrm{C}=\mathrm{O}), 820$ - 868. (m) (Ar-CH).

\subsection{Synthesis of Polymer}

\subsubsection{Synthesis of Poly (Styrene-Co-DEAMVA) with 5 and $20 \mathrm{~mol} \%$ of DEAMVA (II a,b)}

A mixture of 5 and $20 \mathrm{~mol} \%, 0.544 \mathrm{~g}$ and 1.632 respectively of

2-[(diethylamino)methyl]-4-formyl-6-methoxyphenyl acrylate, $4 \mathrm{~g}$ (0.038 mol) styrene and $10^{-3} \mathrm{~mol} \%$ AIBN of the total mole $\%$ of monomers was dissolved in $50 \mathrm{~mL}$ toluene and added in $100 \mathrm{ml}$ round bottom flask. The reaction mixture was purged in argon for $20 \mathrm{~min}$, and then heated in oil bath at $70^{\circ} \mathrm{C}-80^{\circ} \mathrm{C}$ with stirring for $6 \mathrm{~h}$. After cooling at room temperature and also in refrigerator, the polymer was precipitated by solvent evaporation using rotatory evaporator. Polymer was purified by dissolved in THF, and re-precipitated in diethylether to remove the unreacted monomers and impurities. Yield \%: 94\%, and 86 for 5, and $20 \mathrm{~mol} \%$ respectively, Physical state: Yellowish white solid.

${ }^{1} \mathrm{H}$ NMR (500 $\left.\mathrm{MHz}, \mathrm{CDCl}_{3}\right): \delta(\mathrm{ppm})=0.50-2.71\left(\mathrm{~m}, 9 \mathrm{H}, \mathrm{CH}, \mathrm{CH}_{2}\right.$-styrene 
repeating unit, $\left.2 \mathrm{CH}_{3} \mathrm{DEAMVA}\right), 3.25$ - $3.93\left(\mathrm{~m}, 9 \mathrm{H}, 2 \mathrm{CH}_{2}, \mathrm{NCH}_{2}, \mathrm{OCH}_{3}\right.$ DEAMVA), 4.60 - 5.13 (m, 3H, $\mathrm{CH}, \mathrm{CH}_{2}$-DEAMVA repeating unit), 6.30 - 7.52 (m, 6H, H-Ar), 9.75 - 9.97 (br., 1H, -CHO).

IR (KBr): $v\left(\mathrm{~cm}^{-1}\right): 2990(\mathrm{~s})$ (CH-Aliphatic), 1720-1743 (s) $(-\mathrm{C}=\mathrm{O}), 1134(\mathrm{~s})$ $\left(-\mathrm{OCH}_{3}\right)$.

\subsubsection{Synthesis of Grafted 20 mol\% (III a) Poly (Styrene-Co-DEAMVA) with Tryptophan (IV) as a Function of $\mathrm{pH}$}

In $50 \mathrm{ml}$ round bottom flasks $1.0 \mathrm{~g}$ of $20 \mathrm{~mol} \% \mathrm{P}$ (Styrene-Co-DEAMVA) and $1.0 \mathrm{~g}$ of (tryptophan) was dissolved in $30 \mathrm{~mL}$ THF. The reaction was taken place in different $\mathrm{pH}$ solutions ( $\mathrm{pH} 4, \mathrm{pH}, \mathrm{pH} 9, \mathrm{pH} 10, \mathrm{pH} 12)$ by addition of $\mathrm{NaOH}$ and $\mathrm{HCl}$. The mixtures were stirred gently for $2 \mathrm{~h}$ at room temperature. Solvent was evaporated under reduced pressure. The precipitate was dissolved in THF and re-precipitate in diethylether at $-40^{\circ} \mathrm{C}$ to remove impurities and unreacted molecules. Physical state: Brownish solid.

${ }^{1} \mathrm{H}$ NMR and IR of Poly (Styrene-Co-DEAMVA)-g-Tryptophan at pH12 (IV)

${ }^{1} \mathrm{H}$ NMR (500 MHz, DMSO): $\delta(\mathrm{ppm})=0.70-1.22\left(\mathrm{~m}, 6 \mathrm{H}, 2 \mathrm{CH}_{3}, \mathrm{DEAMVA}\right)$, $1.30-1.65\left(\mathrm{~m}, 1 \mathrm{H}, \mathrm{CH}\right.$ repeating Styrene), $1.82-2.35\left(\mathrm{~m}, 2 \mathrm{H}, \mathrm{CH}_{2}\right.$ repeating styrene), $2.80-2.90\left(\mathrm{~m}, 2 \mathrm{H}, 2 \mathrm{NCH}_{2}, \mathrm{DEAMVA}\right), 3.30-3.40\left(\mathrm{~m}, 2 \mathrm{H}, \mathrm{CH}_{2}\right.$, DEAMVA), $6.10-6.34$ (m, 1H, C=CH, tryptophan), $6.80-7.85$ (m, 9H, H-Ar), 8.5 - 8.6 (br. (s), $1 \mathrm{H}, \mathrm{CH}=\mathrm{N}$ ), 9.30 - 9.942 (s) $1 \mathrm{H}, \mathrm{NH}$, tryptophan).

IR (KBr): $v\left(\mathrm{~cm}^{-1}\right):$ 2995(m) (CH-Aliphatic), 1663-1650 (s) (7-C=O), 1570 - 1560 (s) $(4-\mathrm{CH}=\mathrm{N}), 1026-1107$ (s) $\left(8-\mathrm{OCH}_{3}\right)$.

\section{Results and Discussion}

\subsection{Synthesis of Monomer, Copolymers and Grafted Copolymers}

Scheme 1 describes the chemical procedure for synthetizing monomer, copolymers and grafted copolymers. Monomer (II) or

2-[(diethylamino)methyl]-4-formyl-6-methoxyphenyl acrylate and abbreviated by (DEAMVA), it was fabricated in two steps reaction. The first step Is the formation of (3-[(diethylamino)methyl)-4-hydroxy-5-methoxy-benzaldehyde) and has been done by the reaction of vanillin with diethylamine and formaldehyde according to Mannich reaction mechanism. In this reaction we did not use any catalysis especially acid catalysis which famous to use in Mannich reaction. The second Step Is the formation of

2-[(diethylamino)methyl]-4-formyl-6-methoxyphenyl acrylate (DEMAVA). This was achieved by reaction of compound (I) with acryloyl chloride in the presence TEA to form (II). They have chemically evaluated by ${ }^{1} \mathrm{H}$ NMR and ${ }^{13} \mathrm{C}$ and FT IR in Figure 1, Figure 2 and Figure 5. All data was in logic state and proved the presence of active aldehyde group at $9.97 \mathrm{ppm}$ and $196 \mathrm{ppm}$.

To improve the functionality of styrene free radical polymerization with 5 and 20 mol\% of DEAMVA has been done in the presence of AIBN as initiator as described in Scheme 1. The chemical structure of each polymer was evaluated 


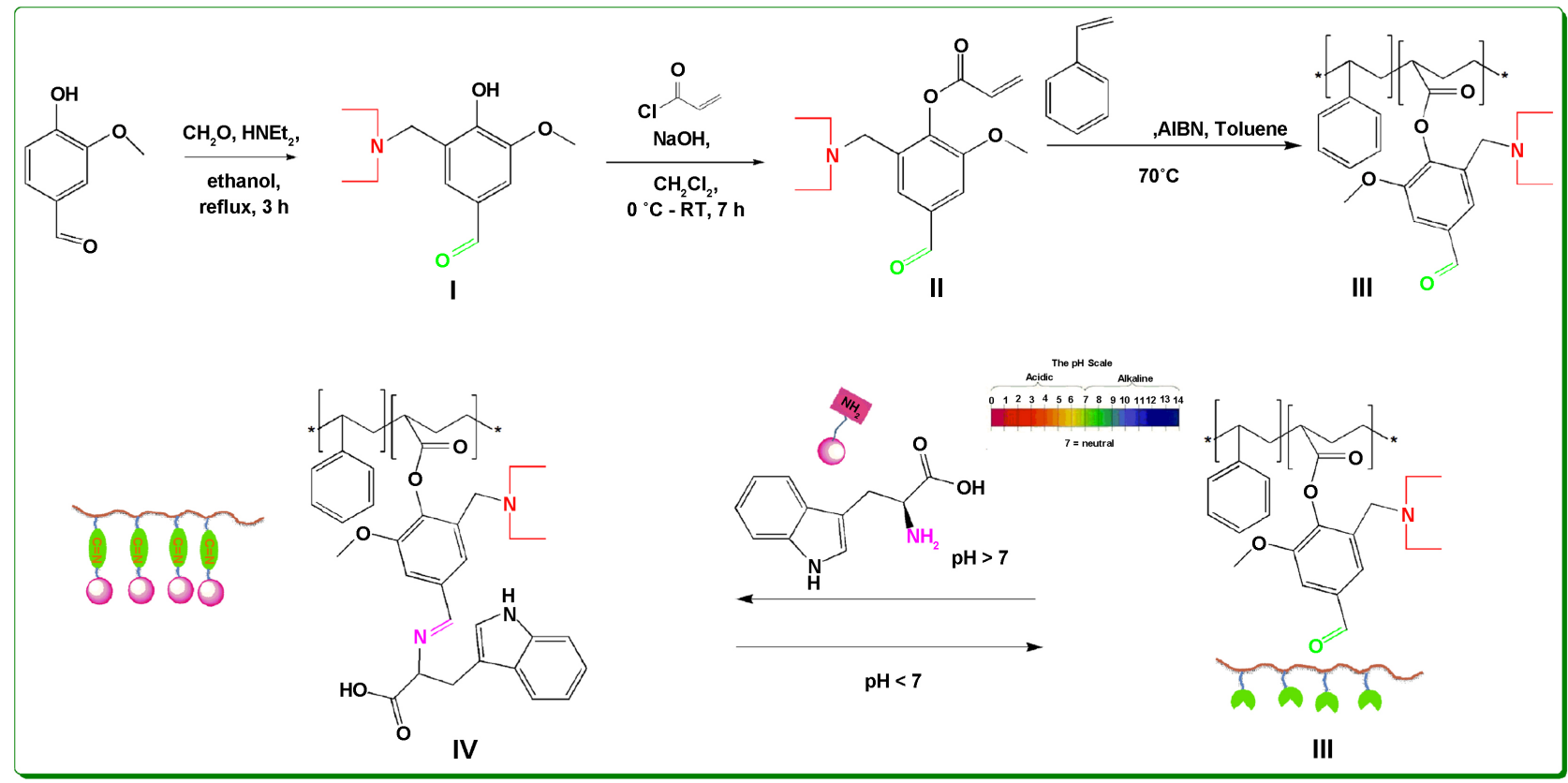

Scheme 1. Synthesis of DEAMVA, copolymers and grafted polymers with Tryptophan.

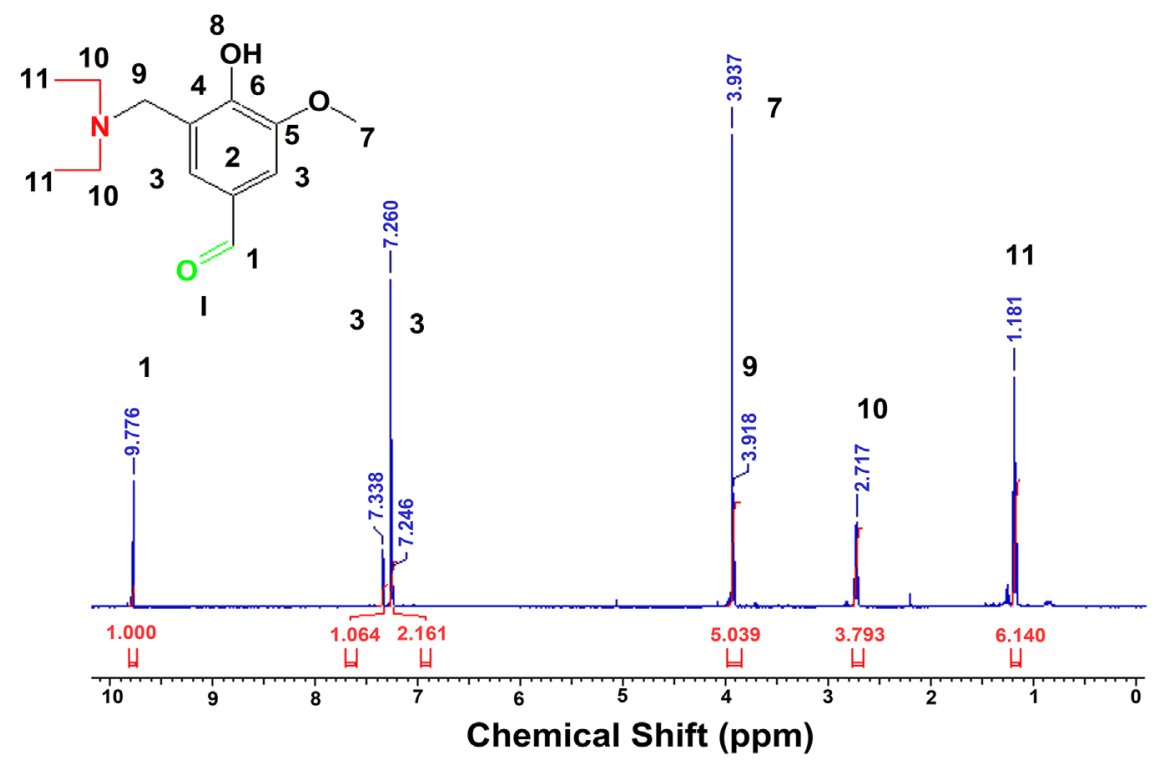

Figure 1. ${ }^{1} \mathrm{HNMR}\left(\mathrm{CDCl}_{3}\right)$ of 2-[(diethylamino)methyl]-4-formyl-6-methoxyphenyl acrylate.

by ${ }^{1} \mathrm{H}$ NMR and FT IR as shown in Figure 3 and Figure 5 . The ${ }^{1} \mathrm{HNMR}$ of copolymers II a-b showed specific broad multiples peaks at $\delta=0.73-1.35 \mathrm{ppm}$ of $2 \mathrm{CH}_{3}$ DEAMVA, at $\delta=7.08-7.62 \mathrm{ppm}$ of Ar-H of each styrene and DEAMVA, and at $\delta=9.94$ of H-CHO of DEAMVA monomer. FT IR showed the presence of ( $\mathrm{C}=\mathrm{O}$ stretch) ester at $1745 \mathrm{~cm}^{-1}$. The actually composition of each monomer in the copolymer chain was calculated from ${ }^{1} \mathrm{H}$ NMR spectra by the ratio of the intensity of the signals at $6.66 \mathrm{ppm}$ (for $\mathrm{H}, \mathrm{Ar}-\mathrm{H}$ styrene) with signal at $9.94 \mathrm{ppm}$ (for CHO of DEAMVA) as cleared in Table 1. 

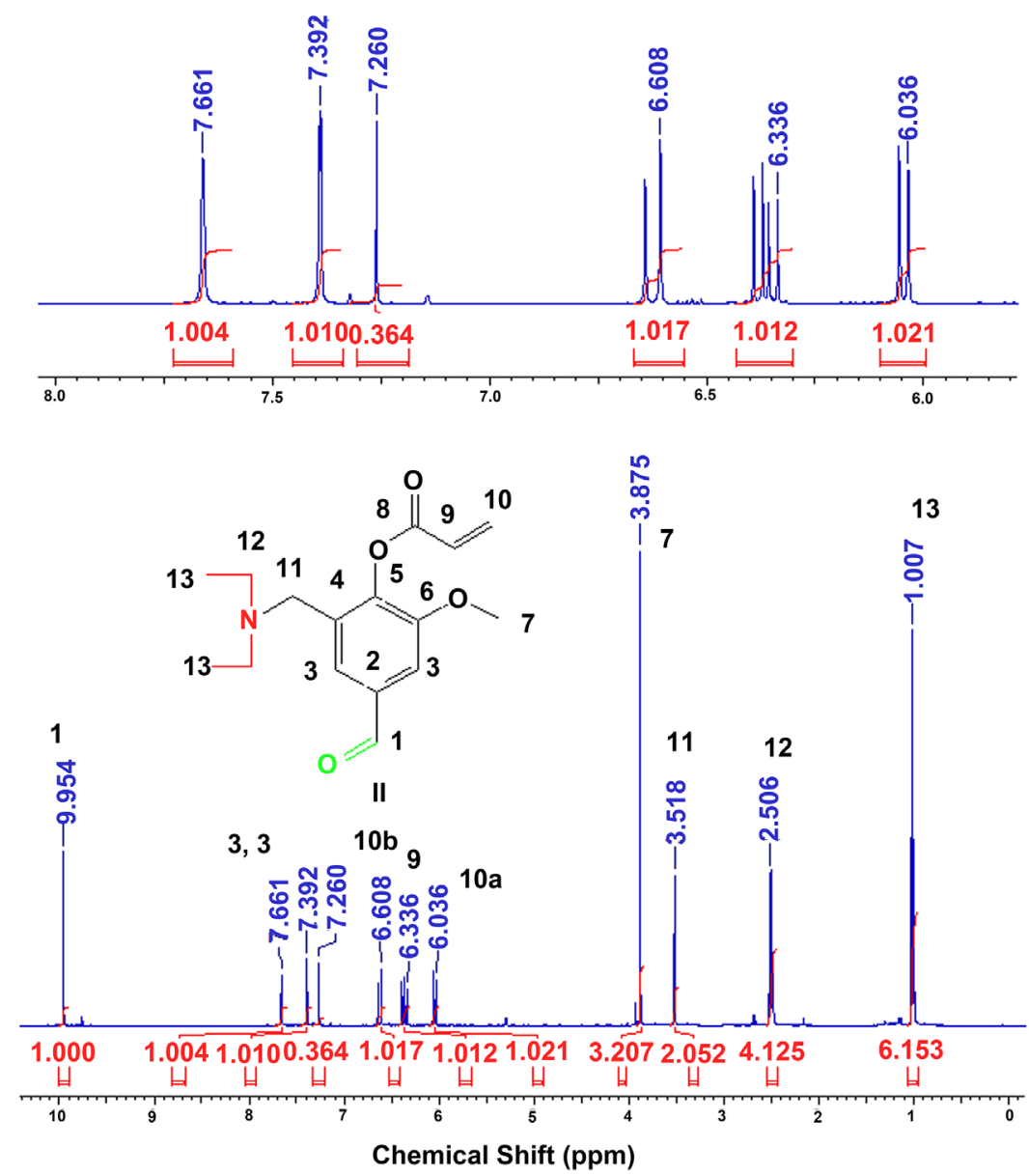

Figure 2. ${ }^{1} \mathrm{H} \mathrm{NMR}\left(\mathrm{CDCl}_{3}\right)$ of

2-[(diethylamino)methyl]-4-formyl-6-methoxyphenyl acrylate (DEMAVA).

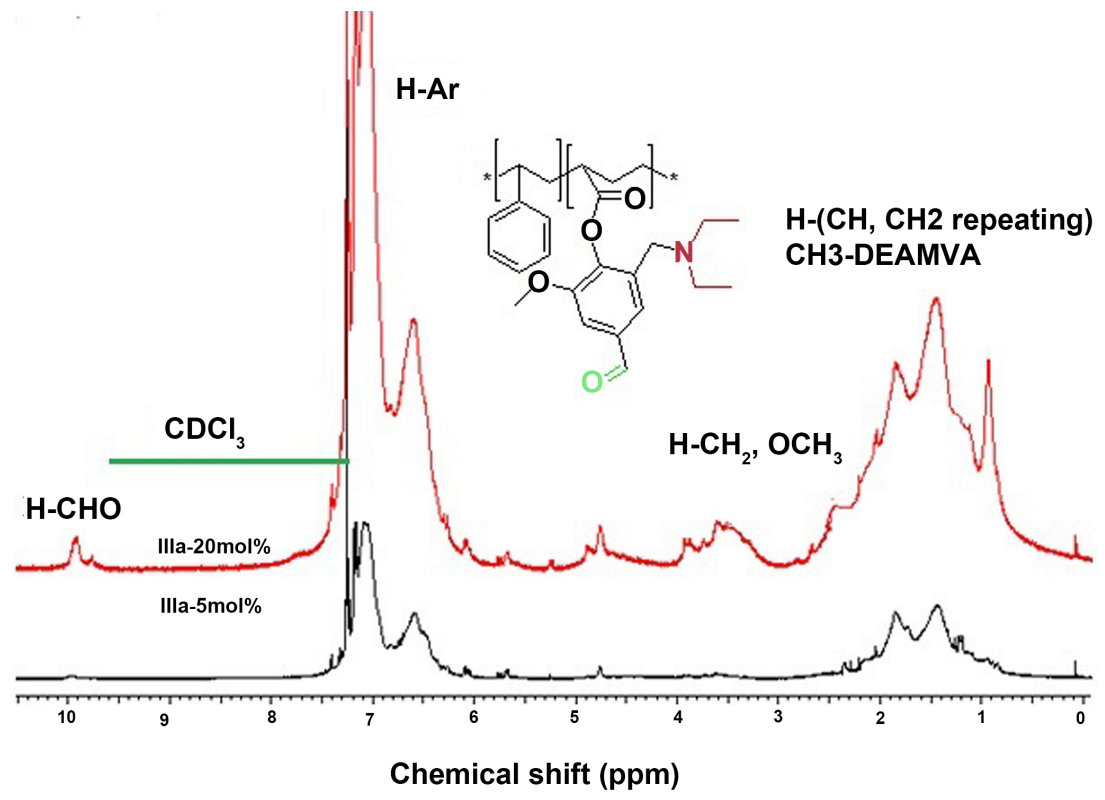

Figure 3. ${ }^{1} \mathrm{H} \mathrm{NMR}$ spectra $\left(\mathrm{CDCl}_{3}\right)$ of $\mathrm{P}$ (Styrene-Co-DEAMVA) 5, 20 mole ratio of DEAMVA. 
Table 1. Yield, composition, conversation, number average molecular weight, polydispersity, and glass temperature of, Poly (Styrene-Co-DEAMVA) 5, 20 mole ratio of DEAMVA and grafted Poly (Styrene-Co-DEAMVA).

\begin{tabular}{ccccccc}
\hline Polymer & $\begin{array}{c}\text { Yield } \\
(\%)\end{array}$ & $\begin{array}{c}{ }^{1} \text { HNMR } \\
\text { DEAMVA (mol\%) }\end{array}$ & $\begin{array}{c}\text { Conversion } \\
(\%)\end{array}$ & $\begin{array}{c}\mathbf{M n}^{\mathrm{a}} \\
(\mathrm{g} / \mathrm{mol})\end{array}$ & $\boxplus^{\mathrm{b}}$ & $\mathbf{T}_{\mathrm{g}}^{\mathrm{c}} \quad\left(^{\circ} \mathrm{C}\right)$ \\
\hline III a & 94 & 3.35 & - & 47400 & 1.98 & 110 \\
III b & 86 & 15.67 & - & 18260 & 2.27 & 130 \\
IV & 78 & - & 88 & 16578 & 2.46 & 135 \\
\hline
\end{tabular}

${ }^{a}$ Number average molecular weight, ${ }^{b}$ Polydispersity, ${ }^{\mathrm{c}}$ Glass transition temperature, ${ }^{\mathrm{d}}$ Lower critical solution temperature.

Functionality with the aldehyde group in the polymer main chain was an interested to make grafting with any amino compound to produce Schiff's base which is familiar by click reaction Scheme 1 . The grafting process has been done at room temperature in THF at different $\mathrm{pH}$ ( $\mathrm{pH} 4, \mathrm{pH}$, $\mathrm{pH} 9, \mathrm{pH} 10, \mathrm{pH} 12)$. Grafted copolymers were elucidated by ${ }^{1} \mathrm{H}$ NMR and FT IR as shown in Figure 4 and Figure 5. The ${ }^{1} \mathrm{H}$ NMR showed the disappearance of aldehyde signal at 9.74 $\mathrm{ppm}$ and formation of imino $(\mathrm{HC}=\mathrm{N})$ signal at about $8.5 \mathrm{ppm}$ as shown Figure 4. Figure 5 showed FT IR spectra and proved the presence of $(\mathrm{C}=\mathrm{N}$ stretch $) \mathrm{im}$ ine at about $1563 \mathrm{~cm}^{-1}$.

\subsection{Polymer Characterization}

\subsubsection{Molecular Weight}

Size exclusion chromatography was used for determination of molecular weight $(\mathrm{Mw})$, number average molecular weight $(\mathrm{Mn})$ and polydispersity $(\mathrm{D})$ of polymers using Polystyrene (PS) as standard in $\mathrm{CHCl}_{3}$. Table 1 has summarized all recorded data for all copolymers. Figure 6 shows the relation between molecular weight and $\log$ M as recoded by GPC and demonstrates one peak, proofing the disappearance of low molecular weight like monomers or impurities.

\subsubsection{Conversion of Poly (Styrene-Co-DEAMVA) to Poly(Styrene-Co-DEAMVA)-g-Tryptophan}

The conversion of poly (Styrene-Co-DEAMVA) to poly

(Styrene-Co-DEAMVA)-g-tryptophan through the chemical reaction, absorption has been measured as function with $\mathrm{pH}$ at constant time $2 \mathrm{~h}$ for each run. The polymer solution has diluted to $10^{-3} \mathrm{~W} / \mathrm{V}$ for each measurement. Figure 7 shows the UV.vis. Spectroscopy of grafting reaction between poly(Styrene- $\mathrm{Co}$-DEAMVA) with tryptophan. The relation between wavelength and absorbance proofed the disappearance of $\mathrm{C}=\mathrm{O}$ aldehyde group at $250-270 \mathrm{~nm}$ and formation of new bond at $340-380 \mathrm{~nm}$ of $\mathrm{C}=\mathrm{N}$ imine linkage. The formation of imino linkage has increased with increasing the $\mathrm{pH}$ value starting with $\mathrm{pH} 5$ which showed about zero absorbance and has been increased gradually till the highest value of absorbance $\mathrm{pH} 12$. Figure 8 shows the relation between $\mathrm{pH}$ and absorbance intensity at constant time. 


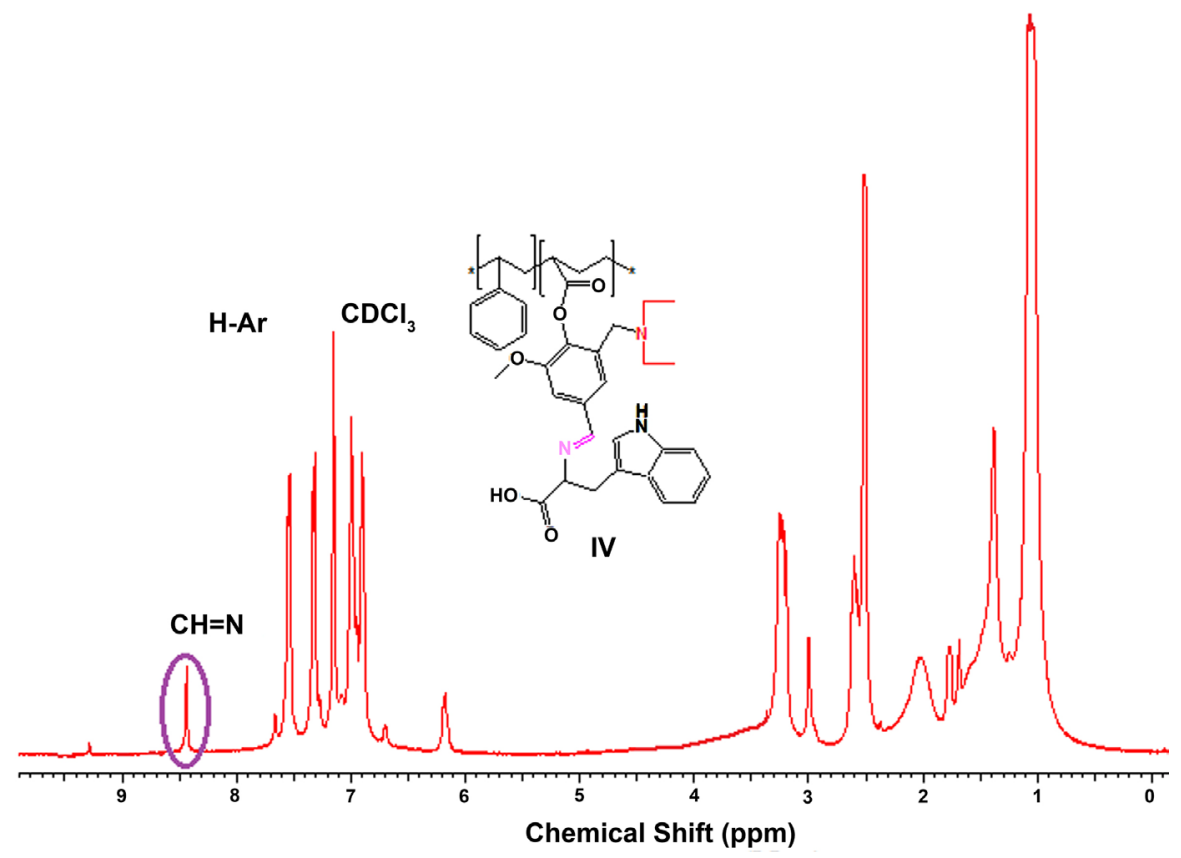

Figure 4. ${ }^{1} \mathrm{H}$ NMR spectra (DMSO) of P (Styrene-Co-DEAMVA)-g-Tryptophan.

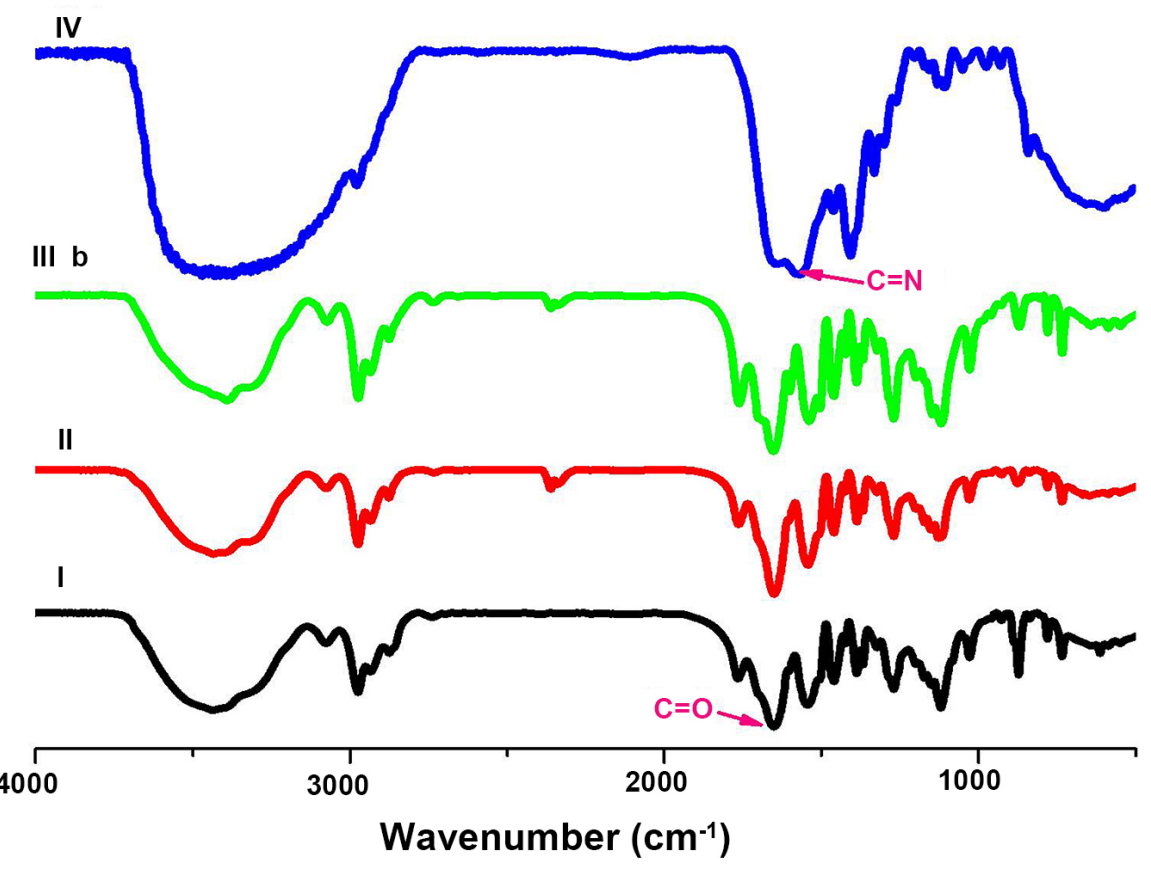

Figure 5. IR spectra KBr for DEAMV (I), DEAMVA (II), Poly (Styrene-Co-DEAMVA) (III b) and grafted copolymers IV.

\subsubsection{Glass Transition Temperature}

The glass transition temperature $\left(T_{g}\right)$ is very important parameters for solid material. It has been recorded by Differential Scanning Calorimeter of dried samples at heating rate $5^{\circ} \mathrm{C} / \mathrm{min}$ as described in experimental part. The $T_{g}$ was taken as the midpoint inflection. The $\left(T_{g}^{\prime} s\right)$ values have been tabulated in Table 1 for copolymers and grafted copolymers. Figure 9 showed a single $T_{g}$ for each 


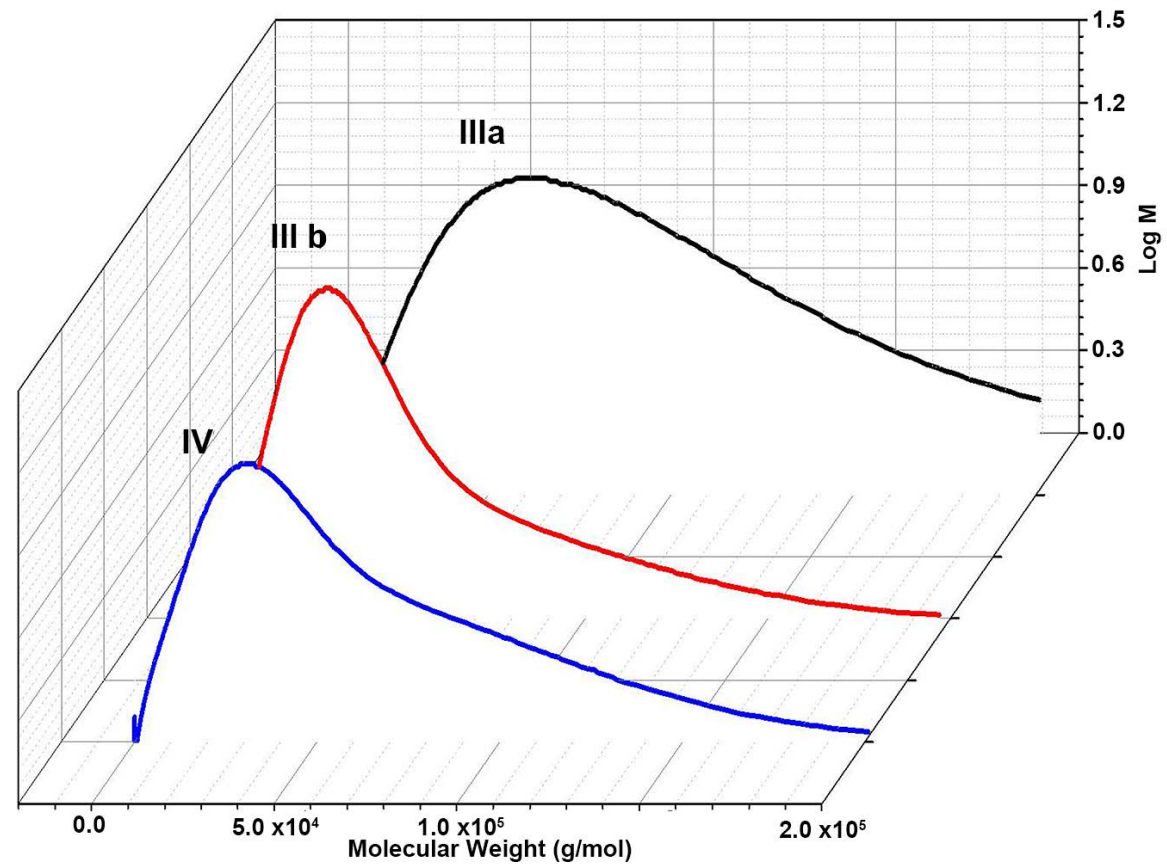

Figure 6. GPC molecular weight of copolymers.

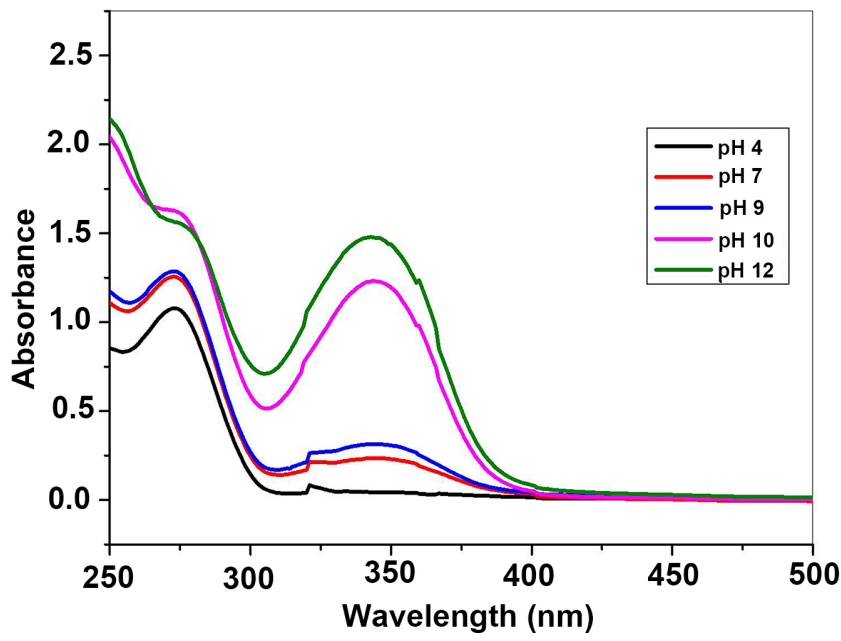

Figure 7. UV-vis. Spectroscopy for the formation of grafted poly (Styrene-Co-DEAMVA)-g-tryptophan as increasing in absorbance from $\mathrm{pH} 5$ - $\mathrm{pH} 12$.

sample, which indicating the formation of random copolymers [36]. The homo-polystyrene (PS) showed $T_{g}$ at $100^{\circ} \mathrm{C}$ [37]. Incorporation of DEAMVA moieties in the copolymers chain with hydrophobic and hydrophilic groups demonstrated in aromatic and tertiary amine respectively resulted in increased $T_{g}$, which might be attributed to decrease in the spacing and hence greater interaction between polymer chains leading to lesser flexibility and $T_{g}$ of the polymer increased [36]. Introducing grafting molecule in copolymer (IV) main chain has directly influenced on raising the $T_{g}$ due to the steric hindrance of aromatic molecule. 


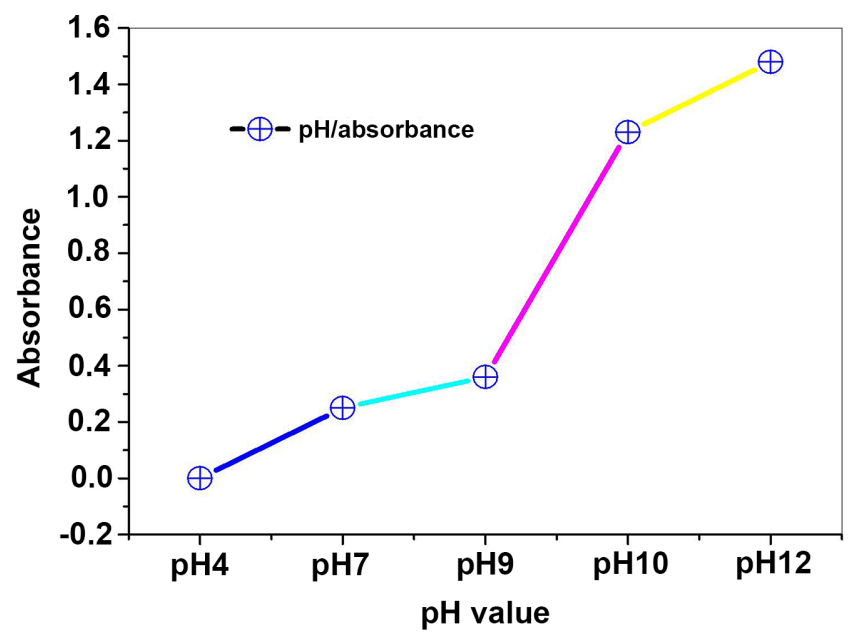

Figure 8. Relation between $\mathrm{pH}$ values to absorbance.

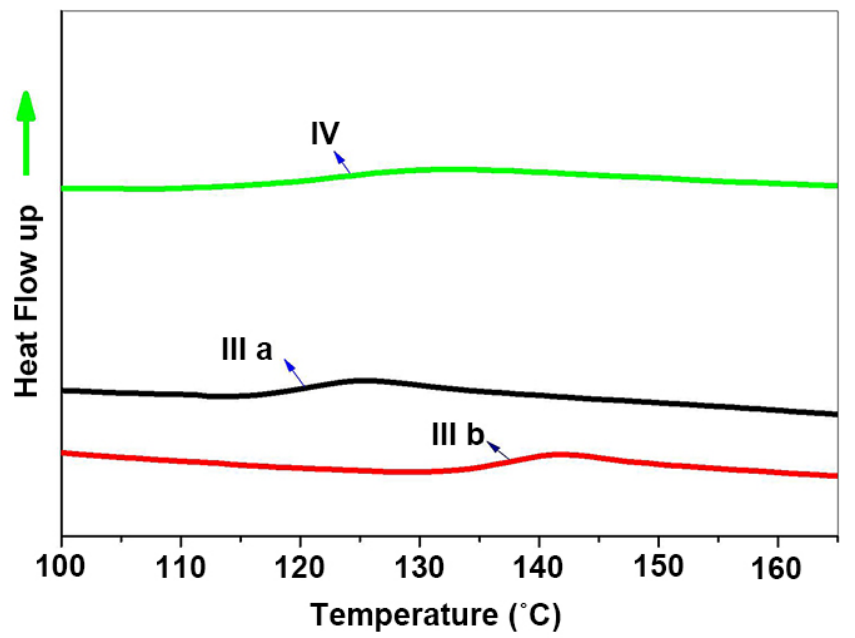

Figure 9. DSC shows the $T_{g}$ of copolymers and grafted copolymer.

\subsubsection{Morphological Feature (SEM)}

Figure 10 is the Scanning Electron Microscopy (SEM) image obtained at a magnification of $1000 \times$ for grafted copolymer (IV). After grafting the porosity of the grafted polymer surface increases the whole surface looks like waxy with cross-linking referring to the imine linkage and grafting of tryptophan.

\section{Conclusion}

Here we synthetized new functional polystyrene copolymers. New $\mathrm{pH}$ responsive monomer with tertiary amine and aldehyde functional groups were prepared in two steps. Free radical polymerization of styrene with two different mole ratios of DEAMVA was used for synthetizing copolymers. The presence of aldehyde group facilitated the formation of Schiff base with primary amine. Tryptophan was used as biological molecule for immobilization. UV-vis. Spectroscopy was used to detect the immobilization and formation of Schiff base at different $\mathrm{pH}$. We observed the highest absorption at $\mathrm{pH} 12$ and lowest at $\mathrm{pH} 4$. In 


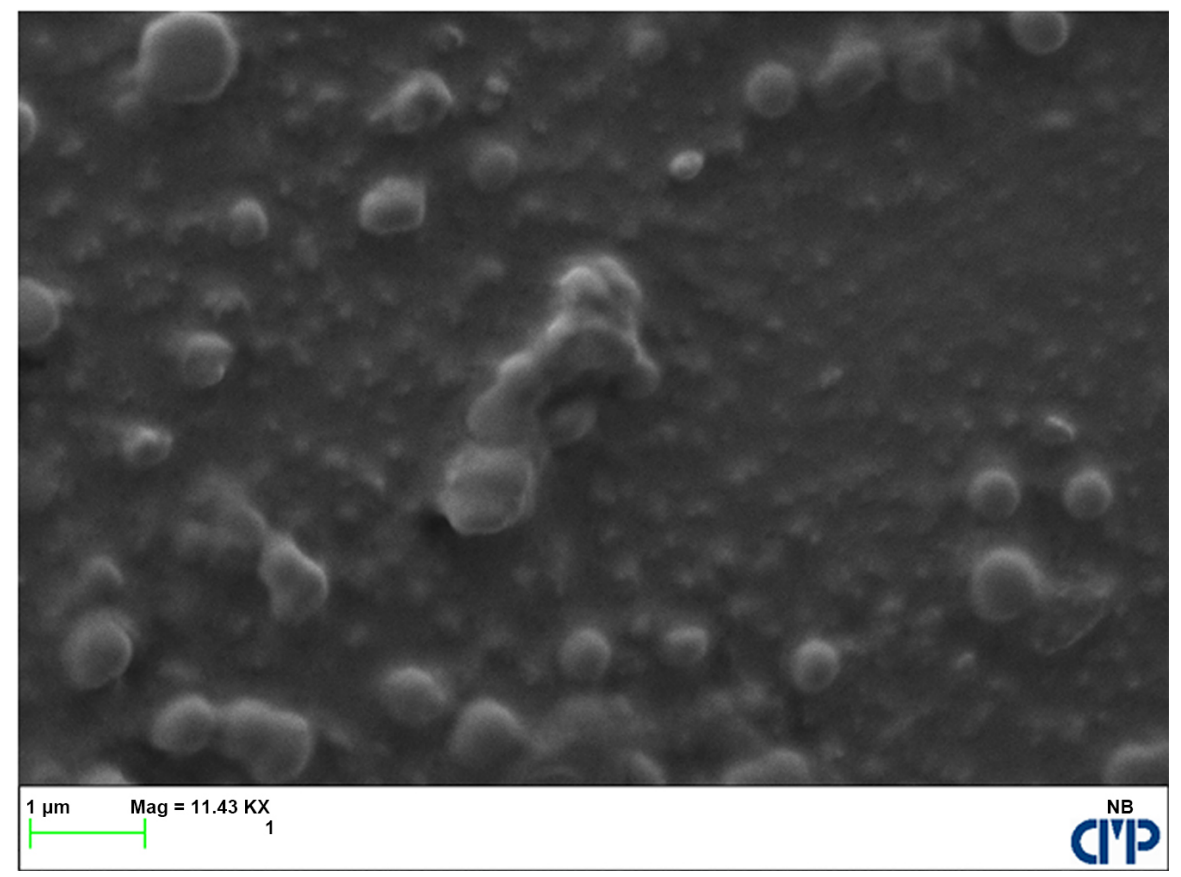

Figure 10. SEM of copolymer IV (grafting) copolymer with tryptophan 1000× magnification.

future, we are looking for using this kind of polymer and its gel in the separation of biomolecules.

\section{Acknowledgements}

The authors are grateful acknowledge to Egyptian culture and missions, and The Deutscher Akademischer Austauch (DAAD) for financial assistance during the post doctor work in Germany of Momen S. A. Abdelaty.

\section{Conflicts of Interest}

The authors declare no conflict of interest.

\section{References}

[1] Young, J.K. and Yukiko, T.M. (2017) Thermo-Responsive Polymers and Their Application as Smart Biomaterials. Journal of Materials Chemistry B, 5, 4307-4321. https://doi.org/10.1039/C7TB00157F

[2] Abdelaty, M.S.A. and Kuckling, D. (2016) Synthesis and Characterization of New Functional Photo Cross-Linkable Smart Polymers Containing Vanillin Derivatives. Gels, 2, 1-13. https://doi.org/10.3390/gels2010003

[3] Sato, E., Masuda, Y., Kadota, J., Nishiyama, T. and Horibe, H. (2015) Dual Stimuli-Responsive Homopolymers: Thermo- and Photo-Responsive Properties of Coumarin-Containing Polymers in Organic Solvents. European Polymer Journal, 69, 605-615. https://doi.org/10.1016/j.eurpolymj.2015.05.010

[4] Chen, J.-K. and Chang, C.-J. (2014) Fabrication and Applications of Stimuli-Responsive Polymer Films and Patterns on Surface. Materials, 7, 805-875.

https://doi.org/10.3390/ma7020805 
[5] Tao, Y.C., Liu, S.W., Zhang, Y., Chi, Z.G. and Xu, J.R. (2018) A pH-Responsive Polymer Based on Dynamic Imine Bonds as a Drug Delivery Material with Pseudo Target Release Behaviour. Polymer Chemistry, 9, 878-884. https://doi.org/10.1039/C7PY02108A

[6] Eiji, Y., Orc, I., Tomohiro, O., Misato, O., Shinjae, P., Atsushi, H., Masamichi, Y., Kazuo, A., Takeshi, T., Norihiko, I., Tomohiro, I. and Yoshiharu, O. (2018) Bleomycin-Loaded pH-Sensitive Polymer-Lipid-Incorporated Liposomes for Cancer Chemotherapy. Polymers, 10, 74.

[7] Kocak, G., Tuncer, C. and Bütün, V. (2017) pH-Responsive Polymers. Polymer Chemistry, 8, 144-176. https://doi.org/10.1039/C6PY01872F

[8] Bazban-Shotorbani, S., Hasani-Sadrabadi, M., Karkhaneh, A., Serpooshan, V., Jacob, K.I., Moshaverinia, A. and Mahmoudi, M. (2017) Revisiting Structure-Property Relationship of $\mathrm{pH}$-Responsive Polymers for Drug Delivery Applications. Journal of Controlled Release, 253, 46-63. https://doi.org/10.1016/j.jconrel.2017.02.021

[9] Ankit, K., Carlo, M. and Hyo-Jick, C. (2017) Smart Microparticles with a pH-Responsive Macropore for Targeted Oral Drug Delivery. Scientific Reports, 7, 3059-3067. https://doi.org/10.1038/s41598-017-03259-x

[10] Liu, L., Yao, W.D., Rao, Y.F., Lu, X.Y. and Gao, J.Q. (2017) pH-Responsive Carriers for Oral Drug Delivery: Challenges and Opportunities of Current Platforms. Drug Delivery, 24, 569-581. https://doi.org/10.1080/10717544.2017.1279238

[11] Jing, X., Anqi, L. and Jianshu, L. (2017) Advances in pH-Sensitive Polymers for Smart Insulin Delivery. Macromolecular Rapid Communications, 38, Article ID: 1700413.

[12] Chen, G. and Hoffman, A.S. (1995) Graft Copolymers That Exhibit Temperature-Induced Phase Transition over a Wide Range of pH. Nature, 373, 49-52. https://doi.org/10.1038/373049a0

[13] Hoffman, A.S., Stayton, P.S. and Bulmus, V. (2000) Really Smart Bioconjugates of Smart Polymers and Receptor Proteins. Journal of Biomedical Materials Research, 52, 577-586. https://doi.org/10.1002/1097-4636(20001215)52:4<577::AID-JBM1>3.0.CO;2-5

[14] Costa, E., Coelho, M., Ilharco, L.M., Aguiar-Ricardo, A. and Hammond, P.T. (2011) Tannic Acid Mediated Suppression of PNIPAM Microgels Thermoresponsive Behaviour. Macromolecules, 44, 612-621. https://doi.org/10.1021/ma1025016

[15] Yang, H.W., Chena, J.K., Cheng, C.C. and Kuo, S.W. (2013) Association of Poly(N-isopropylacrylamide) Containing Nucleobase Multiple Hydrogen Bonding of Adenine for DNA Recognition. Applied Surface Science, 271, 60-69. https://doi.org/10.1016/j.apsusc.2013.01.074

[16] Fache, M., Darroman, E., Besse, V., Auvergne, R., Sylvain Caillol, S. and Boutevina, B. (2014) Vanillin, a Promising Biobased Building-Block for Monomer Synthesis. Green Chemistry, 16, 1987-1998. https://doi.org/10.1039/C3GC42613K

[17] Ananda, S.A., Bernard, W. and Ashfaqur, R. (2012) Vanillin Based Polymers: I. An Electrochemical Route to Polyvanillin. Green Chemistry, 14, 2395-2397. https://doi.org/10.1039/c2gc35645g

[18] Ananda, S.A. and Ashfaqur, R. (2012) Vanillin-Based Polymers-Part II: Synthesis of Schiff Base Polymers of Divanillin and Their Chelation with Metal Ions. Polymer Science, 1, 1-5.

[19] Mohammed, I.A. and Hamidi, R.M. (2012) Synthesis of New Liquid Crystalline Diglycidyl Ethers. Molecules, 17, 645-656. https://doi.org/10.3390/molecules17010645 
[20] Ahmed, M.K., Reham, A.A., Osama, M.D., Ahmed, I.H., Afaf, A.N. and Samira, T. (2017) Synthesis, Characterization, and Evaluation of Antimicrobial Activities of Chitosan and Carboxymethyl Chitosan Schiff-Base/Silver Nanoparticles. Journal of Chemistry, 2017, Article ID: 1434320.

[21] Firdaus, M. and Meier, M.A.R. (2013) Renewable Copolymers Derived from Vanillin and Fatty Acid Derivatives. European Polymer Journal, 49, 156-166. https://doi.org/10.1016/j.eurpolymj.2012.10.017

[22] MialonLVanderhenst, R., Pemba, A.G. and Miller, S.A. (2011) Polyalkylenehydroxybenzoates (PAHBs): Biorenewable Aromatic/Aliphatic Polyesters from Lignin. Macromolecular Rapid Communications, 32, 1386-1392. https://doi.org/10.1002/marc.201100242

[23] Srinivasa Rao, V. and Samui, A.B. (2008) Molecular Engineering of Photoactive Liquid Crystalline Polyester Epoxies Containing Benzylidene Moiety. Polymer Chemistry, 46, 7637-7655. https://doi.org/10.1002/pola.23064

[24] Sini, N.K., Bijwe, J. and Varma, I.K. (2014) Renewable Benzoxazine Monomer from Vanillin: Synthesis, Characterization, and Studies on Curing Behaviour. Journal of Polymer Science Part A: Polymer Chemistry, 52, 7-11.

https://doi.org/10.1002/pola.26981

[25] Shimasaki, T., Yoshihara, S. and Shibata, M. (2012) Preparation and Properties of Biocomposites Composed of Sorbitol-Based Epoxy Resin, Pyrogallol-Vanillin Calixarene, and Wood Floor. Polymer Composites, 33, 1840-1847. https://doi.org/10.1002/pc.22327

[26] Xin, Y. and Yuan, J. (2012) Schiff s Base as a Stimuli-Responsive Linker in Polymer Chemistry. Polymer Chemistry, 3, 3045-3055. https://doi.org/10.1039/c2py20290e

[27] Zhou, L., Cai, Z., Yuan, J., Kang, Y., Yuan, W. and Shen, D. (2011) Multifunctional Hybrid Magnetite Nanoparticles with pH-Responsivity, Superparamagnetism and Fluorescence. Polymer International, 60, 1303-1308.

[28] Lyas, G., Burak, A., Serkan, K., Oguz, Y.S., Emel, Y. and Selahattin, S. (2017) Synthesis of Imine Bond Containing Insoluble Polymeric Ligand and Its Transition Metal Complexes, Structural Characterization and Catalytic Activity on Esterification Reaction. Designed Monomers and Polymers, 1, 441-448.

[29] Etika, K.C., Cox, M.A. and Grunlan, J.C. (2010) Tailored Dispersion of Carbon Nanotubes in Water with pH-Responsive Polymers. Polymer, 51, 1761-1770. https://doi.org/10.1016/j.polymer.2010.02.024

[30] Oda, Y., Kanaoka, S. and Aoshima, S. (2010) Synthesis of Dual pH/TemperatureResponsive Polymers with Amino Groups by Living Cationic Polymerization. Journal of Polymer Science Part A: Polymer Chemistry, 48, 1207-1213. https://doi.org/10.1002/pola.23882

[31] Yan, Q., Zhou, R., Fu, C., Zhang, H., Yin, Y. and Yuan, J. (2011) $\mathrm{CO}_{2}$-Responsive Polymeric Vesicles That Breathe. Angewandte Chemie International Edition, 50, 4923. https://doi.org/10.1002/anie.201100708

[32] Dondoni, A. and Marra, A. (2012) Recent Applications of Thiolene Coupling as a Click Process for Glycoconjugation. Chemical Society Reviews, 41, 573-586. https://doi.org/10.1039/C1CS15157F

[33] Fu, R. and Fu, G. (2011) Polymeric Nanomaterials from Combined Click Chemistry and Controlled Radical Polymerization. Polymer Chemistry, 2, 465-475. https://doi.org/10.1039/C0PY00174K

[34] Franc, G. and Kakkar, A.K. (2010) Click Methodologies: Efficient, Simple and 
Greener Routes to Design Dendrimers. Chemical Society Reviews, 39, 1536-1544. https://doi.org/10.1039/b913281n

[35] Iha, R.K., Wooley, K.L., Nyström, A.M., Burke, D.J., Kade, M.J. and Hawker, C.J. (2009) Applications of Orthogonal "Click" Chemistries in the Synthesis of Functional Soft Materials. Chemical Reviews, 109, 5620-5686.

https://doi.org/10.1021/cr900138t

[36] Gupta, S., Kuckling, D., kretschmer, K., Choudhary, V. and Adler, H.J. (2007) Synthesis and Characterization of Stimuli-Sensative Micro- and Nanohydrogel Based on Photocrosslinkable Poly(Dimethylaminoethyl Methscrylate). Journal of Polymer Science Part A: Polymer Chemistry, 45, 669-679. https://doi.org/10.1002/pola.21846

[37] Mark, J.E. (2009) Polymer Data Handbook. 2nd Edition, Oxford University Press, Oxford.

\section{Graphical Abstract}

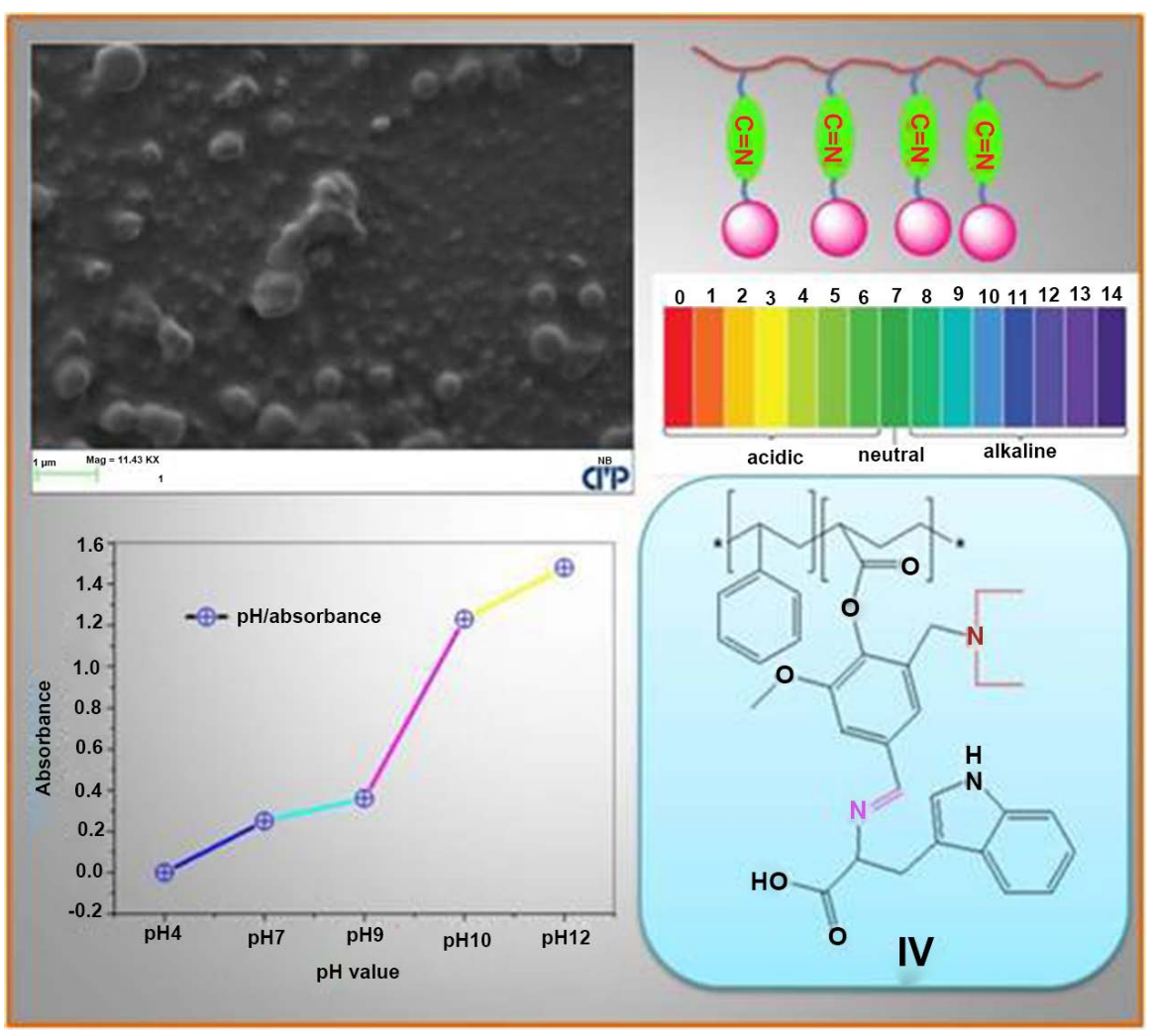

